$\begin{array}{ll} & \text { Etnográfica } \\ \text { etnográfica } & \text { Revista do Centro em Rede de Investigação em }\end{array}$ Antropologia

vol. $23(3) \mid 2019$

Vol. $23(3)$

\title{
Uma passagem entre as duas Américas: mito e ritual ticuna
}

A passage between both Americas: Ticuna myth and ritual

\section{Edson Tosta Matarezio Filho}

\section{(2) OpenEdition}

\section{Journals}

\section{Edição electrónica}

URL: https://journals.openedition.org/etnografica/7214

DOI: 10.4000/etnografica.7214

ISSN: 2182-2891

\section{Editora}

Centro em Rede de Investigação em Antropologia

\section{Edição impressa}

Data de publição: 1 outubro 2019

Paginação: 579-604

ISSN: 0873-6561

\section{Refêrencia eletrónica}

Edson Tosta Matarezio Filho, «Uma passagem entre as duas Américas: mito e ritual ticuna», Etnográfica [Online], vol. 23 (3) | 2019, posto online no dia 27 novembro 2019, consultado o 20 janeiro 2022. URL: http://journals.openedition.org/etnografica/7214 ; DOI: https://doi.org/10.4000/ etnografica. 7214

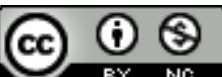

Etnográfica is licensed under a Creative Commons Attribution-NonCommercial 4.0 International License. 


\section{Uma passagem entre as duas Américas: mito e ritual ticuna}

\section{Edson Tosta Matarezio Filho}

Seguindo a pista deixada por Lévi-Strauss de que a análise de um mito ticuna imporia uma "passagem de um continente ao outro", contribuo para a hipótese de que a mitologia deste povo pode ser pensada como operando a transição entre as mitologias indígenas da América do Sul e do Norte. Ao invés do clássico mitema do "desaninhador de pássaros", a mitologia ticuna teria como um de seus personagens um "desaninhador de frutas". Deste modo, estas narrativas estariam relacionadas menos com a origem do fogo, como acontece nas histórias do "desaninhador de pássaros", que com a origem dos adornos, da carne de caça e humana. Assim como as narrativas da América do Norte, a cultura está mais associada com a origem do vestuário do que da culinária. Uma "torção" análoga acontece nas trocas rituais entre os Ticuna. Enquanto o padrão de troca ritual sul-ameríndio é entre carne e bebidas, durante as Festas da Moça Nova ticuna, bebidas e/ou carnes são trocadas por adornos.

PALAVRAS-CHAVE: ticuna, mitologia, ritual, troca.

A passage between both Americas: Ticuna myth and ritual - Following the trail left by Lévi-Strauss when suggesting that the analysis of a Ticuna myth would impose a "passage from one continent to the other," I contribute to the hypothesis that the mythology of this people can be thought as operating the transition between the indigenous mythologies of South and North America. Instead of the classic mitema of the "bird nester," Ticuna mythology would have as one of its characters a "fruit nester." Thus, these narratives would relate less to the origin of fire, as in the stories of the "bird nester," than to the origin of adornments, game meat and human flesh. Like in the narratives from North America, culture is more closely associated with the origin of clothing than that of cooking. An analogous "twist" occurs in ritual exchanges between the Ticuna. While the pattern of South Amerindian ritual supposes the exchange of meat for drinks, during the ritual of female initiation among the Ticuna, drinks and/or meat are exchanged for adornments.

KEYWORDS: Ticuna, mythology, ritual, exchange.

MATAREZIO FILHO, Edson Tosta (sociais@hotmail.com) - Departamento de Antropologia, Universidade de São Paulo, Brasil. 
"PEIXE SOLÚVEL, não serei eu o peixe solúvel, nasci sob o signo de Peixes e o homem é solúvel em seu pensamento! A fauna e a flora do surrealismo são inconfessáveis".

(André Breton, "Manifesto do surrealismo", p. 21)

\section{DE UM CONTINENTE AO OUTRO:}

\section{LITERATURA, ETNOGRAFIA E MÉTODO}

Não é um mero acaso que Lévi-Strauss tenha iniciado o terceiro volume das Mitológicas, A Origem dos Modos à Mesa (2006 [1968]), com um mito dos ticuna, "O caçador Monmaneki e suas mulheres". ${ }^{1}$ Por este povo ocupar uma posição "mais setentrional" na América do Sul em relação ao conjunto anterior de mitos que ele havia analisado, a narrativa ticuna imporia uma "passagem de um continente ao outro” (Lévi-Strauss e Eribon 2005 [1988]: 191). A análise dos mitos ticuna deve levar em conta que a mitologia deste povo opera a transição entre as mitologias da América do Sul e do Norte. Se em O Cru e o Cozido (Lévi-Strauss 2004a [1964]) o eixo privilegiado é o espacial, em A Origem dos Modos à Mesa (2006 [1968]) - livro que inicia a incursão da análise nas terras mais setentrionais do continente -, o eixo temporal está em primeiro plano (Sztutman 2009: 298). Isso contribui para demonstrar que os mitos ticuna fazem uma passagem para a América do Norte, sendo, portanto, bastante frutífera a comparação entre os continentes passando por estes mitos. Uma das evidências desta passagem são os comentários de Lévi-Strauss sobre o mito "Os erros de Cimidyuë" (Nimuendaju 1952: 148-150), narrativa que está à beira de se assimilar ao gênero romanesco, devido à exploração do eixo temporal nos moldes deste gênero ${ }^{2}$, algo que aparece mais nas narrativas dos

l Os ticuna conformam uma população atual de mais de 53 mil pessoas no Brasil - segundo o website "Povos Indígenas no Brasil", do Instituto Socioambiental (ISA), com base em dados de 2014 do Siasi/ Sesai (ver < https://pib.socioambiental.org/pt/Povo:Ticuna >, última consulta em outubro de 2019) -, cerca de 8 mil na Colômbia e 6 mil no Peru (Goulard 2009: 25). São o mais numeroso grupo indígena no Brasil e na Colômbia, falantes de uma língua pertencente ao grupo yurí-ticuna (Carvalho 2009; Goulard e Montes Rodríguez 2013; Montes Rodríguez 2016: 14; Seifart e Echeverri 2014; Soares 2017: 268, n. 10). Contudo, como a língua yurí é considerada extinta, os ticuna são falantes isolados do seu idioma.

2 Sobre o encadeamento sintagmático preciso, característico das narrativas míticas, Lévi-Strauss faz o seguinte comentário para o caso do mito de Cimidyuë: "Não poderíamos obter nada de comparável no caso das aventuras de Cimidyuë, pois com exceção de alguns marcos esparsos e difíceis de articular, o número dos episódios, a ordem na qual estão dispostos e os tipos a que pertencem parecem resultar de uma invenção mais livre, pronta para se liberar das imposições do pensamento mítico, se é que já não o fez. Em outras palavras, podemos nos perguntar se a história de Cimidyuë não ilustraria uma passagem significativa do pensamento mítico para o gênero romanesco, cuja curva é mais flexível e não obedece às mesmas determinações" (2006 [1968]: 106). 
índios norte-americanos. Tal ponto de vista do antropólogo francês, portanto, nos autoriza a explorar ainda mais as comparações com os mitos norte-ameríndios. ${ }^{3}$

Pensando as duas Américas como um grande grupo de transformações que encadeia todas as narrativas míticas de seus povos originários (Lévi-Strauss 1993 [1991]; Descola e Matarezio Filho 2016), abordarei algumas questões relativas à inserção dos mitos ticuna no grande sistema transformacional mítico da América, delineado por Lévi-Strauss nas chamadas Mitológicas. ${ }^{4}$ Os avanços desta obra lévi-straussiana na análise dos mitos ameríndios serão as principais referências metodológicas deste artigo.

Como material de análise utilizei muito do que está registrado na etnografia pioneira de Curt Nimuendaju sobre os ticuna. Este etnógrafo alemão teve seu primeiro contato com os ticuna em 1929, passando apenas 15 dias entre eles (Nimuendaju 1982 [1929]). Muitos anos depois, ele despende um tempo maior entre estes índios, seis meses em 1941 e cinco meses em 1942. A monografia, fruto destes períodos de campo, será de importância fundamental para as análises dos mitos ameríndios empreendidas por Lévi-Strauss em todos os volumes das Mitológicas. Os dados fornecidos por Nimuendaju nos acompanharão ao longo de todo o texto. Utilizo também o mito de origem registrado em Oliveira Filho (1988) e alguns dados etnográficos presentes em Gruber (1998, 1999). O principal etnógrafo contemporâneo dos ticuna com o qual dialogo é Jean-Pierre Goulard (2009), que traz muitas referências dos ticuna do Peru e da Colômbia.

Contudo, uma parte mais atual e considerável das informações provém do trabalho de campo que desenvolvo junto a este povo desde 2012, quando comecei a fazer campo para minha pesquisa de doutorado. Ao longo da pesquisa sempre me impressionou a quantidade e a variedade de narrativas míticas dos ticuna. Tive a oportunidade desde então de registrar e traduzir dezenas de mitos, trabalho que desenvolvo até o momento. ${ }^{5}$ Em minhas investigações,

3 Lévi-Strauss é bem explícito sobre esta necessidade de se comparar certas narrativas ticuna com os mitos norte-americanos, ao mencionar o mito ticuna que conta a história do caçador Monmaneki. "[U]m episódio se destaca no mito tukuna escolhido como referência, no qual uma esposa humana, cortada em dois pedaços, sobrevive parcialmente se agarrando às costas do marido. Este episódio, impossível de interpretar a partir da cadeia sintagmática, e que o conjunto da mitologia sul-americana não esclarece, só pode ser elucidado se for remetido a um sistema paradigmático tirado dos mitos da América do Norte. A transferência geográfica impõe-se, assim, empiricamente" (2006 [1968]: 11).

4 Ver também o filme documentário O Que Lévi-Strauss Deve aos Ameríndios (2013, LISA-USP), disponível em < www.vimeo.com/lisausp/levi-strauss > (última consulta em outubro de 2019), onde surge a entrevista realizada com Philippe Descola integralmente transcrita em Descola e Matarezio Filho (2016).

5 As principais comunidades ticuna onde realizei meu campo foram Nossa Senhora de Nazaré e Vendaval, ambas localizadas no município de São Paulo de Olivença (AM, Brasil). Outras comunidades nas quais permaneci poucos dias também foram importantes para compor a etnografia, bastante focada na Festa da Moça Nova: Belém do Solimões, Campo Alegre, Vila Independente, Umariaçu I e II [continua] 
meu foco etnográfico são as chamadas Festas da Moça Nova, o ritual de iniciação feminina dos ticuna e principal ritual deste povo. Este aporte de dados e análises sobre as festas me proporcionou ir além da análise dos mitos ticuna e suas conexões com os mitos norte-ameríndios. Nas páginas finais deste artigo faço algumas considerações sobre as trocas rituais ameríndias, em geral, e as trocas que acontecem neste ritual ticuna, em particular. Veremos que algumas torções que encontramos na passagem da mitologia para a América do Norte aparecem de forma análoga no ritual.

\section{O DESANINHADOR DE FRUTAS}

Os mitos que contam as aventuras dos gêmeos Yoi e Ipi são os mais conhecidos entre os ticuna e foram bastante registrados. ${ }^{6} \mathrm{O}$ final da saga dos dois irmãos narra a origem do povo ticuna. Neste mito, Yoi - o herói cultural - manda Ipi - o enganador - buscar jenipapo para pintar o filho do último, que acabara de nascer. Ipi só encontra árvores sem fruta. Yoi o manda "voltar e subir na árvore bem no alto. Subiu, mas só viu dois frutos" (Oliveira Filho 1988: 100). Yoi diz para ele pegar um só. "Mas toda vez que Ipi tentava alcançar a fruta, Yoi fazia a árvore crescer mais e mais”. Este último, então, manda crescer uma orelha-de-pau (Polyporus sanguineus ou Pycnoporus sanguineu) no tronco para impedi-lo de subir mais. Ipi se transforma em formiga tucandeira e diminui o jenipapo para poder descer. "Lá embaixo se transformou em gente de novo" (Oliveira Filho 1988: 102).

No mito de origem ticuna, portanto, diferente do desaninhador de pássaros, ${ }^{7}$ seja bororo ou norte-americano, Ipi sobe na árvore para apanhar a fruta de jenipapo. Vejamos um trecho de $\mathrm{O}$ Homem $\mathrm{Nu}$ que pode esclarecer estas inversões ticuna do desaninhador de pássaros:

"Pois bem, havíamos mostrado em $O$ cru e o cozido e lembrado resumidamente em Do mel às cinzas [...] que o ciclo sul-americano do desaninhador de pássaros pertence a um vasto grupo de transformações que permite passar da invenção do fogo de cozinha para a da carne, de um lado, e para a dos adornos e acessórios, do outro" (Lévi-Strauss 2011 [1971]: 50).

Ou seja, o grupo de transformações a que pertence o clássico mito do desaninhador relata a origem tanto da carne de caça como dos adornos. Veremos que a origem de alguns adornos também se encontra no mito de origem dos ticuna,

[continuação] (localizadas no município de Tabatinga, AM); Santa Clara (do município de São Paulo de Olivença); Porto Lima (do município de Benjamin Constant).

6 Ver Nimuendaju (1952), Goulard (2009), Oliveira Filho (1988), dentre outros.

7 Lévi-Strauss abre o primeiro volume das Mitológicas, O Cru e o Cozido (2004a [1964]), com a "Ária do desaninhador de pássaros”. Este motivo será recorrente também ao longo dos outros volumes. 
o que o conecta a algumas versões norte-ameríndias. Deste modo, temos as duas principais "invenções" do referido "vasto grupo de transformações" em uma única narrativa ticuna. Primeiramente, nos detenhamos na "invenção da carne" e sua relação com o surgimento dos magüta, de quem descendem os atuais ticuna. ${ }^{8}$

Com diferentes tipos de isca, os diferentes povos foram pescados, e isto influenciou o atual tom de pele destas pessoas. Juntamente com os povos, as caças também foram pescadas. Transcrevo abaixo o trecho do mito coletado por mim que narra estas diferentes origens. Esta sequência continua a narrativa que estávamos acompanhando acima:

"Ipi ralou a si próprio enquanto estava ralando o jenipapo e se espremeu. Sua mulher o ajudou. Yoi jogou o bagaço de jenipapo no rio Eware e cercou para não escapar. O bagaço foi jogado na água e virou piabinha (tonõniacü), uma piracema $\left(u^{\prime} u\right)$ deste peixe. Quando os peixinhos começaram a subir, Yoi foi pescá-los. Primeiro foram pescados os queixadas (Tayassu pecari), com caroço de tucumã. Ele também usou macaxeira descascada para pescar os alemães, por isso que eles são tão brancos. Usou milho para pescar os americanos. Os ticuna (magüta) foram pescados com macaxeira com casca. Por isso que eles têm a pele escura e por isso que os alemães e americanos têm a pele clara.

A onça foi pescada com carne crua. Ipi foi pescado sem isca. Yoi tentou pescá-lo, mas não conseguiu, só a mulher de Ipi conseguiu. Yoi falou: 'está aqui o caniço para você pescar seu marido'. Quando ela baixou o caniço, Ipi pulou e mordeu o anzol sem isca. Então Ipi tentou pescar, mas ele cacetava os peixes. O irmão dele o alertou, 'não é assim, você está matando as pessoas'. Então Ipi parou de cacetar e pescou os peruanos com casca de macaxeira também" [mito ticuna registrado pelo autor]. ${ }^{9}$

Temos, portanto, um mito ticuna que narra a origem da carne - de caça e humana -, derivada da transformação de Ipi em jenipapo, sua ralação, transformação em peixe e pescaria subsequente. Esquematizando a narrativa, o mito apresenta as seguintes origens:

8 A palavra magüta é usada atualmente como etnônimo dos ticuna e significa o movimento de lançar a linha e a isca que estão amarradas na vara de pesca. Esta palavra tem um sentido geral de "arremesso", por exemplo quando se lança uma pedra com uma baladeira, ou uma flecha com o arco, ou a linha de pesca, em suma, se refere a jogar coisas em geral (ver Nimuendaju 1952: 135). O movimento inverso seria pogüta, palavra que veremos logo abaixo, quando se puxa o caniço, trazendo o que se está pescando.

9 Mito narrado em português por Francisco Alexandre Filho (Üpetücürüngütchiãcü), da comunidade de Nossa Senhora de Nazaré, município de São Paulo de Olivença (AM), Brasil. 


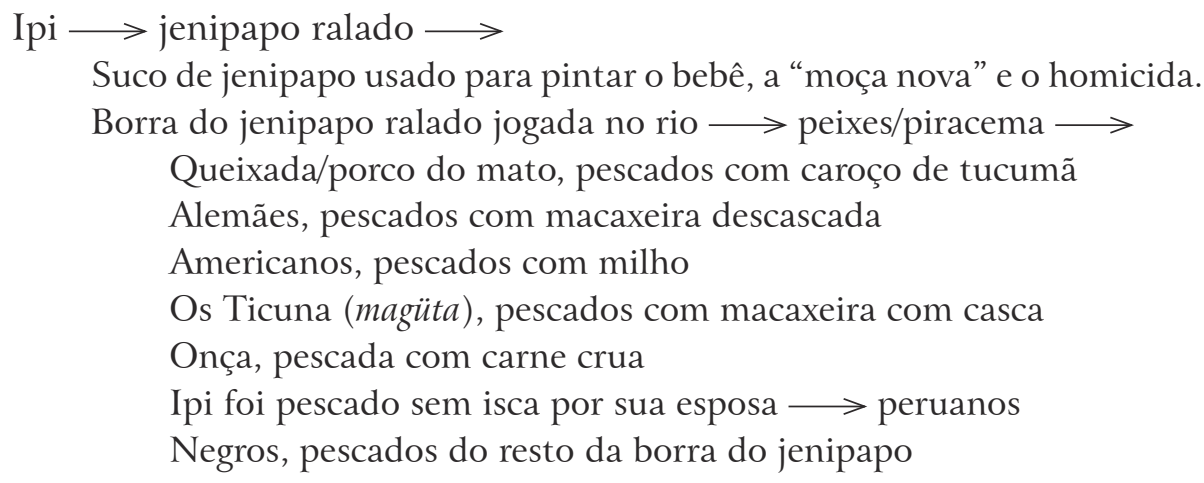

Primeiro são pescadas as caças, com o caroço do tucumã. Um outro narrador nos explica que o caroço tem relação com a dentição forte dos queixadas e caititus: "Os queixadas e caititus têm os dentes fortes porque foram pescados com tucumã, que é duro. Os dentes das pessoas são mais fracos porque elas foram pescadas com isca de macaxeira, que é mole". ${ }^{10}$ Esta referência aos dentes não aparece nas outras versões que tenho deste mito. Ou seja, a isca diferente criou seres diversos, com dentições e tons de pele diversos. Mas, notemos bem, é como se o ser pescado já fosse em potência aquilo em que a pescaria o transformará. Determinada isca era alvo de determinado ser, deste modo o ser já possuía o paladar de seu devir futuro. Bastou que Yoi o estimulasse com a isca para a transformação se completar. Yoi fisga peixes com um paladar de queixada - isto é, peixes que possuem uma qualidade transespecífica, um gosto pelo mesmo alimento que os queixadas e caititus (Pecari tajacu) -, mas a transformação se consuma ao "puxar a pesca" (pogüta). Ao saírem da água, puxados para a terra pelo caniço, os peixes que comem tucumã se transformam em queixadas e caititus.

Após a pescaria da caça, os diferentes povos são pescados também. O mesmo motivo da diferenciação dos povos de acordo com a cor da pele aparece entre os povos do sul da Califórnia. Os diferentes tipos humanos, classificados de acordo com a cor da pele, emergem da exposição diferenciada da argila moldada ao sol. ${ }^{11}$ Entre os ticuna, o tom da pele é dado de acordo com a cor do alimento, ou da casca do alimento, no caso da macaxeira, usados como isca para o peixe. Os ticuna foram pescados com macaxeira com casca, por isso eles têm a pele escura, ao contrário dos alemães, que têm a pele clara, pois foram

10 Trecho de mito retirado de um trabalho escolar, na escola estadual da comunidade ticuna de Vendaval, município de São Paulo de Olivença (AM), em 2013.

11 Ver Lévi-Strauss (1986: 189). Nesta mesma referência, o autor relata a relação de transformação entre os mitos ticuna e do norte da Califórnia. “Também em L’homme nu (pp. 36-40) comparei os mitos tukuna a mitos provenientes de regiões ao norte da Califórnia, que os reproduzem quase que literalmente" (Lévi-Strauss 1986: 227). 
pescados com macaxeira sem casca. Mas voltemos à figura do gêmeo Ipi, central nesta parte final do mito para compreendermos esta especiação.

Antes que Ipi jogasse a borra de jenipapo no rio, foi preciso que ele copulasse com sua cunhada. Um pouco atrás na ordem da narrativa, surge este trecho do mito que aqui nos interessa, conhecido como "Filha do Umari" ou "Moça do Umari”, assim apresentado na versão do mito coletada por Nimuendaju:

"Yoi e Ipi foram participar da festa da puberdade de sua sobrinha, a filha do esquilo [quatipuruzinho], Ta'üne, que havia se casado com sua irmã Aiküna [...]. Ipi não reconheceu seu cunhado e, enquanto os irmãos estavam voltando da celebração, ele repetidamente perguntou quem tinha sido o anfitrião, mas Yoi sempre respondia que não sabia. Na festa tinha sido arranjado para que Yoi, não Ipi, ficasse com a garota. No entanto, Ipi insistiu que ele queria casar com ela e para este propósito queria voltar para casa de Ta'üne, mas ele não conseguia mais encontrar o caminho.

Enquanto isso, a menina já havia chegado à casa dos irmãos. No quintal havia uma grande árvore de umari ${ }^{12}$ [T., të̈tchi]. A moça se transformou em uma fruta umari, a única na árvore, de onde seu nome Të'tchi-arü-ngui ['Garota do Umari']. Assim que ele a viu, Ipi quis pegar a fruta, mas Yoi o proibiu. Então Ipi varreu o chão limpando debaixo da árvore, a fim de encontrar a fruta assim que ela caísse, e esperou a sua hora.

Yoi foi caçar, matou muitos pássaros, e voltou, cansado e manchado de sangue. Depois de dar os pássaros para Ipi limpar e depenar, ele saiu para tomar banho. Enquanto isso, a fruta umari caiu. A menina assumiu novamente a forma humana e esperou Yoi, que logo se juntou a ela. Ele rolou ela entre as palmas das mãos, reduzindo seu tamanho até que foi capaz de escondê-la dentro de sua flauta de osso. Muito mais tarde, Ipi terminou seus trabalhos e, voltando para casa, viu imediatamente que a fruta não estava mais sobre a árvore, nem no chão. Ele acusou o irmão de ter comido ou escondido, mas Yoi respondeu que provavelmente alguma cutia a tinha levado embora.

Durante quatro dias, Yoi levou à noite a menina para sua rede, brincando com ela em silêncio. Sempre um pouco antes do amanhecer, ele a escondia mais uma vez em sua flauta de osso. Na quinta noite, ela riu com ele e os sinos feitos de conchas de pequenos caracóis em suas braçadeiras tilintou. 'Meu irmão', perguntou imediatamente Ipi, 'com quem você está rindo?' 'Nada', respondeu Yoi. 'A vassoura riu porque eu fazia cócegas nela!' Então Ipi levantou, pegou uma vassoura com um sino de concha de caracol amarrado, deitou-se com ela em sua rede e começou a fazer cócegas na vassoura. 'Irmão', reclamou ele, 'a vassoura não ri!' 'Pois', respondeu Yoi, 'a minha 
sim!' Quando, na noite seguinte, Ipi voltou a ouvir o riso da moça, ele começou a perguntar quem estava com Yoi, e este respondeu que estava brincando com o quiriká, ${ }^{13}$ Ipi imediatamente levantou-se para trazer um quiriká para sua rede e começou a fazer cócegas nele. No entanto, ele não riu.

Të'tchi-arü-ngui era agora esposa de Yoi, mas ele continuou a escondê-la na flauta de osso todos os dias antes do amanhecer, para Ipi não vê-la. No entanto, este último estava convencido de que seu irmão tinha uma esposa e ele procurou por toda a parte. Um dia, quando Yoi tinha ido caçar, Ipi tomou seu arco e flechas e pegou uma grande quantidade de peixes pequenos [ainke] no igapó. Ele os trouxe para casa, onde derramou-os em um vaso de barro grande, que ele colocou sobre o fogo. Quando o calor da cerâmica aumentou, os peixes ainda vivos começaram a pular sobre ele. Então Ipi puxou seu pênis para fora de seu cinto peniano e dançou ao redor da fogueira, cantando: 'Tchau tarakunyë'-nyë'-nyë'; com isso, seu pênis começou a balançar para cima e para baixo. ${ }^{14}$

Të’tchi-arü-ngui viu isto de seu esconderijo e não pôde conter o riso. Ipi imediatamente parou e olhou ao redor, escutando atentamente, mas como ele não descobriu nada, ele continuou sua dança. Mais uma vez Të'tchi-arü-ngui teve que rir, e desta vez Ipi descobriu-a dentro da flauta. Ele a puxou para fora, fornicou com ela, e depois tentou colocá-la na flauta novamente, mas ele não poderia fazê-lo, pois ela já estava grande com criança [grávida]" (Nimuendaju 1952: 127-128). ${ }^{15}$

A narrativa segue como resumi acima: Yoi fica bem bravo e manda seu irmão buscar jenipapo para pintar a criança. Demonstrei em outros trabalhos (Matarezio Filho 2015b: 111 passim, 2013, 2015a) que a "Moça do Umari" é também To'oena, a primeira “moça nova”, que aparece em outra narrativa. Ou seja, a moça estava em reclusão quando a história começa e os planos eram que ela se casasse com Yoi. Este chega a ficar um tempo com a moça e a esconde em sua flauta para que seu irmão não a descubra. O motivo da criança escondida ou da mulher guardada em um recipiente - “cesto, caixa, flauta, casulo, fossa subterrânea, colmo do telhado etc." (Lévi-Strauss 2011 [1971]: 39-40) - é encontrado tanto entre os ticuna como entre os lilloet, de língua salish, da América do Norte. Lévi-Strauss mostrou que os relatos são tão próximos que

13 Peça de madeira em forma de meia lua, usada para amassar a mandioca.

14 Segundo me explicaram, ngawü (samotazinho) é o peixe que Ipi fritou no mito de origem dos ticuna. Ele ficou pulando ao redor do forno, com o pênis balançando e falando "tchautaracünhẽ, tchauta-

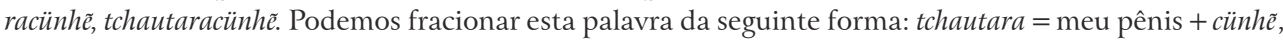
que pode ser traduzido como "choque", como o choque do peixe-elétrico, ou o que acontece quando se toma uma pancada. Ele dizia isso para sua cunhada dar risada e denunciar onde estava escondida. 15 A tradução deste trecho, assim como de outros textos de que se encontram em língua estrangeira na bibliografia, foi feita por mim. 
basta justapor as versões para notar a semelhança. O fato de estar escondida remete, seguindo as pistas da mitologia ticuna, à própria reclusão da "moça nova".

Uma das versões deste mito, fornecida por Nimuendaju e analisada por Lévi -Strauss, mostra um Ipi que pode ser equiparado a um sariguê, devido à forma como copula. ${ }^{16}$ Contudo, nas versóes de Oliveira Filho (1988) e principalmente Goulard (2009), Ipi não se comporta como um sariguê, isto pode indicar uma inversão importante. Ao menos, com esta transformação, este mito perde seu parentesco com o "grupo jê da esposa celeste de um mortal", em que "Estrela é uma sarigüéia, que é violentada pelos cunhados" (Lévi-Strauss 2004a [1964]: 205). O que se inverte agora não é mais a "função sariguê" dos mitos jê, mas, como veremos, a "função desaninhador" destes mitos. A cunhada de Ipi continua descendo à terra - como a estrela dos mitos jê -, pois cai como uma fruta umari da árvore, mas não é mais violentada. Além disso, o mais importante, Ipi não é um desaninhador de pássaros, mas sim um apanhador de fruta.

\section{A PASSAGEM PARA A AMÉRICA DO NORTE}

O mito nez-percé analisado no capítulo "Peixes solúveis" de O Homem Nu (Lévi-Strauss 2011 [ 1971] , cf. M602B e M602C) conta a história de um desaninhador que "atravessou as nuvens" e pôs o pé num mundo "igualzinho à nossa terra". ${ }^{17}$ Como vimos, Ipi não chega a tanto, mas assim como o herói Coiote-Filho, do mito nez-percé, ele é "retardado pelos obstáculos" que seu irmão faz crescerem no jenipapeiro, justamente para ele não subir mais e não chegar à “outra terra”.

"Coiote fica cansado, sofre com o calor, tem sede e se deixa seduzir pela água refrescante de um rio que o leva até as donas dos salmões. Elas o recolhem e adotam, depois de ele ter assumido a aparência de um bebê. Mas Coiote fura a barragem e libera os peixes" (Lévi-Strauss 2011 [1971]: 348).

No mito ticuna, depois que a massa de jenipapo é jogada na água, nada sabemos do destino de Ipi até sua volta, quando sua esposa sente sua falta e (quase) o pesca. A passagem de Coiote bem poderia ter acontecido a Ipi. No fim das contas, a massa de Ipi origina os matrinxãs ${ }^{18}$ ou piabinha (tonõniacü), dependendo da versão, e o próprio Ipi aparecerá como um peixe. Ambos os

16 Esta é a segunda versão do mito, coletada em 1929 por Nimuendaju. O trecho da cópula é o seguinte: "Soprando sobre isso [a flauta em que a moça estava escondida], ele forçou Të'tchi-arü-ngui para fora e teve o coito com ela até que seu esperma exalou de sua boca e narinas" (Nimuendaju 1952: 128).

17 Povo de língua sahaptin, habitantes dos contrafortes das Montanhas Rochosas nos EUA (Lévi-Strauss 2011 [1971]).

18 Designação regional comum dos peixes do gênero Brycon. 
mitos, portanto, tratam da origem dos peixes. No caso de Ipi, até algo mais, pois ele traz ouro na ponta de seu nariz, e em outras narrativas ele traz roupas e panelas (Goulard 2009). Portanto, trata-se de originar algo materialmente valioso, sejam peixes ou ouro. Outra narrativa, o mito do caçador Monmaneki ${ }^{19}$, é indicada por Lévi-Strauss como relativa à origem dos peixes dos ticuna. Neste mesmo sentido, o autor mostra a conexão que o tema da origem dos peixes faz com os mitos da América do Norte:

"Monmaneki cria os peixes a partir de aparas de madeira, tema bastante conhecido alhures, mas cuja área de distribuição, assim como a do tema do homem de pênis longo, engloba as tribos mais setentrionais da América do Norte: esquimós, índios da costa noroeste e da bacia do rio Colúmbia" (Lévi-Strauss 2006 [1968]: 73).

Ao que tudo indica, os mitos ticuna acompanham os mitos "dos Klamath-Modoc até os Salish, os quais todos, e de modo homólogo a Ml, calam ou subentendem a origem do fogo, mas fazem da chuva, da inundação ou de seu equivalente funcional o meio empregado pelo herói para se proteger ou se vingar" (Lévi-Strauss 2011 [1971]: 350). A referência que temos é que, após a saga de Yoi e Ipi, o mundo sofre uma série de inundações, que só cessam depois da proibição do incesto com a instauração dos clãs. ${ }^{20} \mathrm{Na}$ verdade, existe um mito ticuna que narra a origem do fogo (Lévi-Strauss 2004a [1964], M54), mas penso que este acontecimento deve ser localizado antes do nascimento de Yoi e Ipi. ${ }^{21}$

Com relação ao fogo, durante as aventuras de Yoi e Ipi, o fogo não é qualificado como culinário. Trata-se, assim como nos mitos nez-percé, "não de um fogo doméstico, mas de fogueiras ocasionais" (Lévi-Strauss 2011 [1971]: 349). Chegamos a uma explicação da razão por que as narrativas sobre Yoi e Ipi não tratam da origem do fogo. Sendo um desaninhador de frutas, Ipi e seu irmão protagonizam as histórias que originam os adornos, a carne de caça e humana. ${ }^{22} \mathrm{Ou}$ seja, como muitos mitos norte-americanos, "dos klamath aos salish meridionais” (2011 [1971]: 349), as narrativas dos gêmeos ticuna marcam

19 Uma grafia mais atual do nome deste herói seria Mõmanecü. Na versão que coletei deste mito, bem menor que a de Nimuendaju, o caçador é chamado Moe. Este mito também está registrado em Oliveira Filho (1985: 85) e foi retraduzido em Vasques (2010: 42).

20 A organização social ticuna divide as pessoas em clãs que se agrupam em duas metades exogâmicas não nominadas, mas que costumam ser glosadas como "com penas" (clãs de pássaros) e "sem penas" (clãs de outros animais e plantas).

21 Não encontrei referências a este mito em campo.

22 Há uma versão ticuna do "desaninhador de pássaros", mas difere bastante do motivo sul-americano. Nesta versão, ao invés de um dos personagens subir e o outro ficar em baixo, os dois irmãos sobem para matar um gavião-real. Ver Nimuendaju (1952: 124) e Goulard (2009: 396). 
a "passagem", dentro do conjunto de narrativas ticuna, "da categoria de $\mathrm{cru}$ para a de $n u$, e associa $[\mathrm{m}]$ a cultura menos à origem da culinária do que à do vestuário" (Lévi-Strauss 2011 [1971]: 350). No mito que o ticuna Severino Alexandre Gomes (Tõetükü) me contou sobre a origem do dia, com a derrubada da samaumeira que tapava o sol, Ipi sobe o rio que foi criado pelo tronco da grande samaumeira e traz consigo as roupas. ${ }^{23}$ Afinal, diz Severino, naquele tempo "ninguém tinha roupa, só tanga". Neste mito temos mais uma vez a associação de Ipi com o ouro. Na versão de Goulard (2009), ele é um peixe com o nariz dourado. Nesta mesma versão, este herói quando sai da água traz muitas coisas também, como panelas, etc. O relato da origem do dia se encontra, não por acaso, no meio do mito de origem dos ticuna. Desta maneira, os adornos, as roupas e, principalmente, a pintura de jenipapo e a regra de exogamia clânica virão em seguida.

Retomando as semelhanças com os mitos dos nez-percé, o grupo ${ }^{24}$ a que pertence o mito M66l é considerado como possuidor de uma armação "rigorosamente simétrica à da história do desaninhador de pássaros" (Lévi-Strauss 2011 [1971]: 255). Em alguns dos mitos deste conjunto, a história do desaninhador é seguida da liberação dos peixes, sequência que podemos notar no mito ticuna. Além disso, a caça também é criada neste mito, pois são pescados antes dos humanos (2011 [1971]: 329-330). A questão das vestimentas também é uma importante chave para se compreender o mito do desaninhador. Lévi-Strauss chega a comentar que, nas versões norte-americanas deste mito, "a retirada do vestuário pelo herói representa um traço invariante" (Lévi-Strauss 2011 [1971]: 258). Algo que nos faz pensar no fato de Ipi ter, na versão de Goulard (2009), se "vestido" com a fruta do jenipapo. O herói entra, se fecha dentro do jenipapo e, em seguida, ainda dentro da fruta, ele se joga para baixo da árvore. Ele se "veste", portanto, com a própria substância na qual irá se transformar. Algo mais próximo da ideia de ingerir as próprias roupas (motivo norte-americano), do que a atitude típica do desaninhador, despir-se. ${ }^{25}$ Ipi, diferente do desaninhador clássico, não se despe nem definha. O herói se transforma em água (Goulard 2009), no que malogra, ou em formiga (Oliveira Filho 1988) para descer da árvore.

23 Severino era morador da comunidade de Nossa Senhora de Nazaré, em 2012, e atualmente mora em Umariaçu 1. Existem registros de diversas versões deste mito, coletei algumas em campo também. Ele se insere na grande narrativa de origem dos ticuna. Ver Nimuendaju (1952: 124), Goulard (2009), Oliveira Filho (1988) e Gruber (1998).

24 Que inclui as narrativas dos salish da costa, dos chinook e dos sahaptin limítrofes (Lévi-Strauss 2011 [1971]: 329-330).

25 “... pelo fato de ingerir suas próprias roupas, pode-se dizer que ele se veste por dentro, ao passo que o desaninhador, que tira as suas, se despe por fora. E pela mesma razão o herói de M661 se alimenta do de fora - pois que as roupas envolvem o corpo - enquanto o desaninhador, que definha e não tem nada para comer a não ser a própria substância, se alimenta do de dentro" (Lévi-Strauss 2011 [1971]: 331). 
Parece-me que os ticuna possuem uma espécie de "natureza" vegetal, pois são uma transformação da massa de jenipapo. O mesmo é atestado pela etnografia de Goulard (2009) também, sobre os ticuna do Peru e Colômbia. Este autor menciona a "metáfora vegetal" usada para se referir à "moça nova" quando ela está em reclusão. Em muitos momentos ela é referida como uma flor desabrochando. ${ }^{26}$ Além disso, os heróis, ao subirem na samaumeira que Yoi encolhe para desaninharem os filhotes de gavião-real e matá-los, se transformam, um em uma bola de látex negra, o outro num chumaço de algodão branco. ${ }^{27}$ Dois gaviões são mortos e jogados para baixo, para suas irmãs depená-los, dando origem assim aos adornos de penas. Ao subir no jenipapeiro, Ipi também origina um tipo de adorno, a pintura corporal de jenipapo. ${ }^{28}$

Notemos que a ralação do próprio corpo de Ipi e sua transformação em jenipapo tem relação com o mito bororo M20, em que "os heróis se incineram voluntariamente" (Lévi-Strauss 2004b [1967]: 24). Neste, os heróis pegam fogo e se transformam em pássaros, das cinzas nascem algumas plantas (Lévi-Strauss 2004a [1964]: 1 19-120). Trata-se, nas palavras de Lévi-Strauss, de um "procedimento duplamente "ultra-culinário"”, que mantém, assim, uma relação suplementar com seu resultado: o surgimento dos adereços e adornos, igualmente "ultraculinários", pois estão do lado da cultura, enquanto "a cozinha é uma atividade técnica que faz a ponte entre a natureza e a cultura" (Lévi-Strauss 2004b [1967]: 25).

Poderíamos dizer que o procedimento de Ipi - assim como as atitudes dos heróis bororo que se incineram e dão origem aos adornos dos clãs - é duplamente "ultraculinário"? Acredito que sim. Ipi chega a pegar fogo, ao cutucar um tatu defumado. Ele tocou o tatu "com um pau, lambeu os dedos e se queimou como um tronco seco. Não restou mais que cinzas" (Goulard 2009: 397). Ao ralar o jenipapo e além, ralando a si mesmo, o herói do mito ticuna dá origem ao líquido que será utilizado para pintar (adornar) seu filho. Ou seja, é um procedimento culinário - utilizado, por exemplo, na ralação da mandioca - que, em seu excesso (pois que rala o corpo inteiro de Ipi) origina a tintura do jenipapo. A mesma borra de jenipapo originará o povo Magüta, que é pescado com isca de macaxeira, e também a carne de alguma caça (queixada

26 Para uma crítica à ideia de "metáfora vegetal” de Goulard, ver Matarezio Filho (2017: 201).

27 Nas narrativas de Nimuendaju (1952: 124) e Goulard (2009: 396) aparece esta cena de desaninhador "clássico", mas não excluem o desaninhamento do jenipapo mais adiante. Na versão de Nimuendaju, Yoi se transforma em macaco da noite e Ipi em gambá.

28 Segundo os ticuna, a tintura de jenipapo possui um efeito rejuvenescedor para a pele, podendo operar mesmo uma troca de pele em determinados momentos da vida, como durante a passagem das moças para a vida adulta (Matarezio Filho 2015b, 2017). Pensarmos esta troca de pele como uma troca de vestuário não estaria tão distante da própria noção de corpo ameríndia, em que, segundo E. Viveiros de Castro, “a forma manifesta de cada espécie é um envoltório (uma 'roupa') a esconder uma forma interna humana" (Castro 2002: 351 ). 
e porco-do-mato - objetos duplamente "infraculinários"), pescados com isca de tucumã. Principalmente, todas estas transformações, ao contrário do que acontece em M15, Ml6 e M20 (Lévi-Strauss 2004a [1964]), são mediadas pela água, não pelo fogo. A origem dos porcos-do-mato, diz Lévi-Strauss, "recorre, como meio, a diversas substâncias, que mostramos serem variantes combinatórias da fumaça de tabaco" (2004b [1967]: 27). Contudo, como vimos, o meio de origem para os porcos-do-mato, no mito ticuna, é a água.

Ao analisar variantes do mito do desaninhador presentes em todo o continente americano, Lévi-Strauss conclui que "a armação pan-americana de A [o mito do desaninhador de pássaros] permite evocar alternadamente a origem da água (Ml) ou do fogo (M7-Ml2)" (201l [1971]: 250). No entanto, o desaninhador ticuna, como vimos, não evoca nem a origem da água, nem a do fogo. Certamente por não se tratar de um desaninhador, mas de um apanhador de frutos, precisamente, um único fruto de jenipapo. Uma inversão interessante que acontece neste mito ticuna é a dificuldade que Yoi impõe à subida de Ipi no jenipapeiro. Diferente dos desaninhadores clássicos, que, em geral, são impedidos de descer, Ipi é atrapalhado em sua subida, de todas as formas, mas desce até que com certa facilidade e esperteza. A certa altura de $\mathrm{OHomem} \mathrm{Nu}$, Lévi-Strauss mostra a relação de homologia que existe entre "o ciclo sul-americano do desaninhador de pássaros e o que se refere à introdução da vida breve" (2011 [1971]: 257). Podemos considerar o mito de origem dos ticuna menos como um mito de origem de uma etnia do que como um mito que narra como os mortais (yunatü) surgiram, ou seja, a "introdução da vida breve". Assim, os mortais são derivados de peixes que, por sua vez, derivam do bagaço do jenipapo. Contudo, o caldo do jenipapo ralado por Ipi ficou com os imortais (ü’üne) e foi utilizado para pintar seu filho. Esta separação coloca, de um lado, os mortais (bagaço de jenipapo + peixes) - que terão que pegar mais jenipapo para se pintarem, como que complementando algo que foi perdido no mito - e, de outro lado, os imortais que já se beneficiaram com os efeitos do jenipapo.

Veremos, adiante, que esta inversão presente na mitologia ticuna - a armação dos mitos que remetem para a origem do fogo torna-se a armação dos mitos que remetem para a origem da carne e dos adornos - encontra uma transformação correspondente no padrão de trocas rituais entre os sul-ameríndios. Ao invés de os convidados trazerem carne moqueada para ser trocada por bebida oferecida pelos anfitriões, os convidados ticuna trazem os adornos, que são oferecidos em troca de bebida e carne moqueada.

Até aqui podemos notar que Ipi, o enganador ticuna, é um personagem central na mitologia deste povo. A partir deste personagem podemos estabelecer uma estrutura mítica inspirada no Grupo de Klein $\left(\mathrm{X},-\mathrm{X}, \mathrm{X}^{-1},-\mathrm{X}^{-1}\right)$, tantas vezes demonstrada por Lévi-Strauss como correspondendo a uma possibilidade de transformação dos mitos ameríndios. Ipi é o mediador, ele faz a transição entre o mundo dos imortais e dos mortais, passando pelo mundo subaquático. Não 
se torna ele mesmo um mortal, mas é de sua substância misturada à massa de jenipapo que se originam os peixes que serão pescados já como humanos. $\mathrm{O}$ antimediador pode ser pensado como sendo o "demônio" (ngo-o $)^{29}$ mítico Machi'i, já que ele morre ao atingir a fruta de abiu, não tem sucesso em sua colheita e é ferrado por diversos bichos peçonhentos, exatamente o contrário do que acontece com Ipi. ${ }^{30}$ Representa o próprio curto-circuito entre natureza e cultura em si, lugar ocupado pelo veneno na mitologia ameríndia, diz Lévi-Strauss (2004a [1964]: 317). Este demônio cai do alto da árvore como uma presa fulminada pelas flechas envenenadas da zarabatana. Podemos dizer que ele é uma espécie de antidesaninhador $\left(-\mathrm{X}^{-1}\right)$, levando-se em conta que o desaninhador Ipi $\left(\mathrm{X}^{-1}\right)$ está também invertido, pois desaninha uma fruta. $\mathrm{O}$ inverso do desaninhador (X) se encontraria nos mitos de Dona Mergulhão e do menino escondido (-X), analisados por Lévi-Strauss ao longo de $\mathrm{O}$ Homem $N u$. No caso ticuna, é uma mulher escondida, a esposa de Yoi, que está dentro da flauta. ${ }^{31}$ Note-se que é uma mulher muito desejada que está escondida, não um menino. Como vimos, a esposa escondida de Yoi será descoberta por Ipi, que a engravidará. O poder de sedução desta mulher está no fato de ser um fruto de umari, uma fruta muito cheirosa, permitindo que o desaninhador (clássico, X) se oponha à mulher escondida e esta implique num desaninhador de frutas $\left(\mathrm{X}^{-1}\right)$. Esquematicamente, o mesmo Grupo de Klein poderia ser grafado como se apresenta na figura $1 .{ }^{32}$

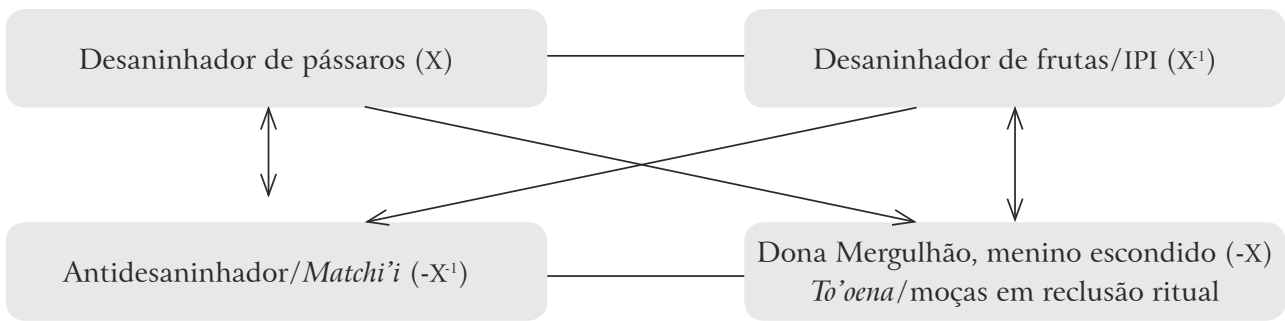

Legenda: Relação de contrariedade $(\longrightarrow)$, relação de contradição $(\longrightarrow)$ e relação de implicação $(\longleftrightarrow)$

Figura 1 - Estrutura mítica.

29 "Ngo'o é bicho que come gente", me disse um ticuna certa vez. Nimuendaju (1952) traduz a mesma palavra como "demônio", o que me foi indicado também algumas vezes como uma possível tradução para o termo.

30 "No caminho ele parou, olhou para trás, e viu uma fruta madura no tronco de uma árvore de abiu quase um palmo acima do chão. Ele tentou pegá-la, apressando-se para trás, mas quando ele se aproximou, a fruta subiu mais alto e logo estava fora de alcance" (Nimuendaju 1952: 125).

31 Que corresponde também à To'oena, a primeira "moça nova" do mito e, no ritual, às moças em reclusão (Matarezio Filho 2015b: 111 ).

32 Este esquema é baseado no quadrado semiótico de Greimas (1973), um equivalente ao Grupo de Klein (ver Almeida 2008). 


\section{A TORÇÃO DO MITO NO RITUAL}

Antigamente, usava-se o iburi, um trompete de casca enrolada, ${ }^{33}$ para convidar as pessoas para a Festa da Moça Nova. ${ }^{34} \mathrm{O}$ instrumento era levado no barco do dono da festa até as outras comunidades. Quando chegavam próximo à comunidade da pessoa a ser convidada, começavam a tocar o trompete. As pessoas ouviam de longe o pessoal chegando no barco. Isso era feito para que os convidados escondessem o tururi, entrecasca usada na confecção das máscaras, pois o dono da festa não pode vê-lo. Ele tem que levar um jenipapo para cada casa de convidado que visita. Nimuendaju nos oferece uma boa descrição de como era feito o "convite definitivo" com o iburi:

"Em geral, os convites definitivos são dados na véspera das festividades, geralmente simultaneamente por mensageiros em duas canoas, uma indo rio acima, outra rio abaixo. Cada homem carrega um grande trompete de casca, iburi $[\ldots]$, coberto com folhas de bananeira para escondê-lo dos olhares de mulheres e crianças quando a canoa chega à margem. Soprando esse instrumento, cujo som pode ser ouvido de longe, os mensageiros viajam de uma casa para outra, contando ao proprietário o dia e a hora exatos (por posição do Sol) quando a cerimônia começará, e verificando a potencial presença ou ausência do convidado" (Nimuendaju 1952: 76).

Segundo um de meus colaboradores, Lorenzo, conhecedor de Festas da

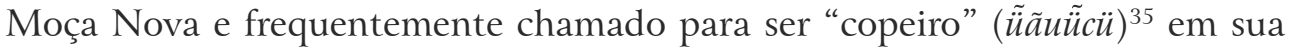
comunidade, Belém do Solimões (Tabatinga, AM, Brasil), o iburi também acompanha a caçada que é feita para juntar o moqueado para a festa:

"Depois que o pajauaru [bebida fermentada de mandioca] está pronto, o dono da festa diz assim, 'vamos caçar', procurando as pessoas que vão com

33 Os ticuna possuem três tipos de trompetes. Um menor, feito de bambu, chamado coĩri, um maior, to'cü, feito do tronco da palmeira paxiuba (Socratea exorrhiza ou I. exorrhisa), e o iburi ou buburi, da casca da árvore duru (Croton palanostigma; Glenboski 1975: 122), de dimensões próximas ao to'cü, cerca de dois metros. Para um estudo mais detalhado destes instrumentos, ver Matarezio Filho (2013, 2015a) e o filme documentário Iburi: Trompete dos Ticuna, de Edson Tosta Matarezio Filho, 2014, São Paulo de Olivença (AM), São Paulo (SP), LISA-USP, FAPESP, disponível em < www.vimeo.com/lisausp/iburi > (última consulta em outubro de 2019).

34 Por questões de espaço no artigo, apresento aqui uma etnografia drasticamente reduzida da complexa Festa da Moça Nova, apenas pinçando os dados referentes às trocas rituais. Uma descrição mais extensa dos três dias de ritual, sua preparação e suas relações com demais âmbitos da vida ticuna podem ser apreciada em minha tese de doutorado (Matarezio Filho 2015b) ou no livro que corresponde a uma versão revista e reduzida da tese (Matarezio Filho 2019).

35 O "copeiro" (baecü ou $\tilde{u} \tilde{a} \tilde{u} c \ddot{u})$ é o encarregado de cuidar para que se cumpra o processo ritual e de servir bebida fermentada (pajauaru) para os convidados, por isso Lorenzo se refere a ele como o "responsável" pela festa. 
ele. Passam duas semanas caçando e pescando. Na caçada levam também o iburi. Tem que levar também, antigamente era assim. Na canoa já iam soprando. As pessoas já estavam sabendo. Para onde for caçar, vai soprando o iburi na canoa. Passados três dias, três semanas, às vezes um mês, a gente

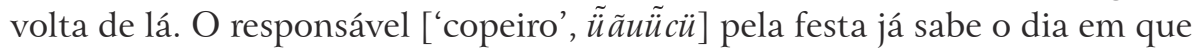
o dono da festa vai voltar. Quando voltam da caçada vêm soprando o iburi também. As pessoas que estão esperando ouvem o iburi e comentam, "lá vem o dono da festa”. Nisso, o responsável já está esperando lá no porto, para receber as pessoas que chegam da caçada. O responsável e a turma dele esperam as pessoas tocando tamborim e leva o moqueado para a casa da moça nova. Tem que procurar lenha para esquentar o moqueado quase todo o tempo, todo dia. Nunca pode faltar lenha debaixo do moqueado, para secar bem" [Lorenzo, comunicação pessoal].

Apesar de Nimuendaju relatar que “[u]m Tukuna raramente se atreverá a vir sem ser convidado" (1952: 75-76), o ticuna Ondino Casimiro (Doctürécurügõecü), ${ }^{36}$ me mostrou um outro ponto de vista. Em tom de brincadeira, ele disse que ticuna é igual a formiga, "nem precisa convidar que eles aparecem. Se chamamos 20, aparecem 40". Ao ser convidada, a pessoa recebe uma sugestão do que levar e confirma que levará tal presente para a festa. Com relação a vir sem ser convidado, Ondino me contou que isso acontece, existem inclusive termos distintos para designar a pessoa que foi convidada e a que não foi mas veio para a festa. Gunegü, ao contrário do aetanü, é o festeiro desconhecido, que não foi convidado. No trecho da "canção que fala sobre o quarto de reclusão da moça nova" (turitchiga), o cantor interpela os dois tipos de festeiro, o não convidado ou não conhecido (gunegü) e o convidado ou conhecido (aetanü):

\section{“Aetanü, aetanücü [Festeiro conhecido] \\ Pa gunegü, gunegü [Festeiro desconhecido, 2x]"}

De acordo com Ondino, atualmente, para se convidar uma determinada comunidade não se pode mandar recado. O dono da festa deve ir pessoalmente fazer o convite, mais ou menos uma semana antes dos festejos. Os itens que serão pedidos pelo anfitrião aos seus convidados não podem ser pronunciados pelo dono da festa. Deste modo, existem recursos linguísticos usados para não falar diretamente o que se está pedindo. Ao chegar na comunidade, o dono diz para os convidados, por exemplo, "costura sua roupa velha". Deste modo, o convidado já sabe que tem que levar tururi para a festa. $\mathrm{O}$ anfitrião usa este 
recurso porque falar a palavra "tururi" pode deixar o dono da festa doente. Ele pode ficar enfeitiçado e não haveria modo de curá-lo. Se ele olhar para o tururi estará correndo risco de vida e caso o dono da festa pronuncie os nomes das dádivas que os convidados trarão para o ritual, a máscara grudará em seu portador e ele se tornará o personagem da máscara. ${ }^{37}$

O mesmo acontece com o antigo bastão de dança $\left(d u^{\prime} p a\right)$ e com as fibras de tucum. No momento do convite, o dono da festa não pode pronunciar o nome destes itens. "Quando faz o primeiro convite, o dono da festa costuma recomendar aos homens que levem os bastões. No entanto, não lhe é permitido pronunciar a palavra $d u^{\prime} p a$, pedindo apenas para confeccionarem o naitchipane ("pau fino')" (Gruber 1999: 11). Pronunciar a palavra "tucum" (nã̃) no momento do convite também pode ser perigoso. "Quando faz a encomenda, o dono não pode usar a palavra tucum, naĩ, mas outras, como towae ["uma dança para as crianças"] ou tarumaa (fibras)" (Gruber 1999: 12).

Outra forma de chamar os convidados é dizer "você tem que tirar taperebá para mim”. A referência ao taperebá (Spondias mombin) é devido à sua força. Quando esta árvore cai, logo nasce de novo. A incumbência de procurar o taperebá que será usado na festa é do "copeiro". O taperebá é usado para fazer o "bastão de ritmo" (aru) e para a "moça nova" segurar enquanto estiver dentro do quarto de reclusão. Na última noite da festa, ela não pode dormir na reclusão; um dos recursos para assegurar isso é o galho de taperebá que fica atravessado no quarto de reclusão, para a moça ficar com os braços para cima, segurando no galho.

Como vimos, o "copeiro" é a pessoa responsável por receber os convidados ainda no porto da comunidade. Especialmente se a casa de festas, como acontece muito, está localizada próxima à margem do rio. Não presenciei este tipo de acolhida dos convidados pelo "copeiro" nas festas das quais tomei parte. Em geral, estes mestres de cerimônia estão bastante atarefados com os preparativos da festa e as sequências de atividades que compõem o ritual e acabam não buscando quem está chegando. Lorenzo, contudo, descreveu para mim a recepção dos convidados, que trazem suas dádivas para a festa:

"Então o copeiro da festa vai receber os convidados no porto, com o tamborim [tutu]. Quem tiver hamaqueira [rede] pode ir colocando na casa, enfileirando. Logo que chegam, o copeiro leva o pessoal para tomar pajauaru, primeiro caldo [de pajauaru], depois pajauaru. Pessoa que trouxer tambor pode dançar, pode bater tambor. Quando chegam os convidados, eles podem ser recebidos com o tracajá [instrumento de percussão, tori]. Depois das 18 horas já pode tocar o tracajá" [Lorenzo, comunicação pessoal].

37 "Se o dono desrespeitar essas normas, a entrecasca ficará grudada na pele do usuário da vestimenta, transformando-o para sempre no sobrenatural que ela representa” (Gruber 1999: 39). 
Os rituais atualmente duram cerca de três dias. Começam no início da noite da sexta-feira e terminam no início da tarde de domingo, podendo se estender um pouco mais. Na noite de sexta-feira (pude ver isso acontecendo em duas festas), os ticuna fazem uma dança para as crianças (towae), como Gruber (1999) também notou. A autora descreve a dança enfatizando os adornos de tucum usados pelos participantes, o que presenciei em outros momentos do ritual:

"Há uma outra dança que também pode ser realizada no início da festa, a qual nunca tive oportunidade de assistir, pois em Belém [do Solimões] raramente ocorre. Trata-se do towae, uma dança para as crianças, em que os participantes carregam fibras de tucum, ainda verdes, que trazem para a festa por sugestão do dono [...]. Os homens costumam transportar as fibras com as pontas amarradas em uma das extremidades do bastão ou numa simples varinha, ao passo que as mulheres as trazem ao redor do pescoço. Para dançar, o tucum é colocado sobre os ombros, com as pontas jogadas para trás, formando uma espécie de manto. A dança é sempre acompanhada dos tamborins. O tambor de carapaça de tracajá só participará se houver crianças da metade 'de penas'. Ao final da dança, os participantes entregam o tucum para o dono da festa, que fica com uma parte e distribui a outra

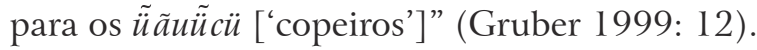

A "dança para as crianças" abre a festividade. Neste momento, em geral, estão presentes as pessoas da comunidade. Os convidados de fora chegarão ao longo do dia seguinte, no sábado, quando acontece a noite principal da festa. O final do trecho de Gruber, acima, aponta o que quero destacar agora: as dádivas entregues pelos convidados para o anfitrião. O convite formal é feito principalmente para as pessoas que serão encarregadas de trazer alguma coisa para a festa. Identifiquei ao menos três dádivas que são trazidas pelos convidados: talos de buriti (figura 2), fibras de tucum e tururi (figura 3). As dádivas são especificadas pelo dono da festa no momento em que ele faz o convite. Assim, o convidado já sabe o que levará para a festa e não há excesso ou escassez dos materiais necessários.

Em duas festas na comunidade de Vendaval, me deram um talo de buriti para eu entrar na casa. Talvez porque seja muito estranho oferecerem tanta bebida para alguém que não trouxe nada para a festa ou não sabe ajudar em nada dos preparativos. A troca ritual ticuna é feita entre, da parte dos anfitriões, as bebidas e a carne moqueada, e, da parte dos convidados e mascarados, os materiais para a fabricação de adornos: tucum, talo de buriti e tururi. Além disso, ao que tudo indica, esta troca acontece em dois planos durante a festa. Chamemos, apenas para fins de análise, um deles de "plano sociológico", a troca entre convidados 


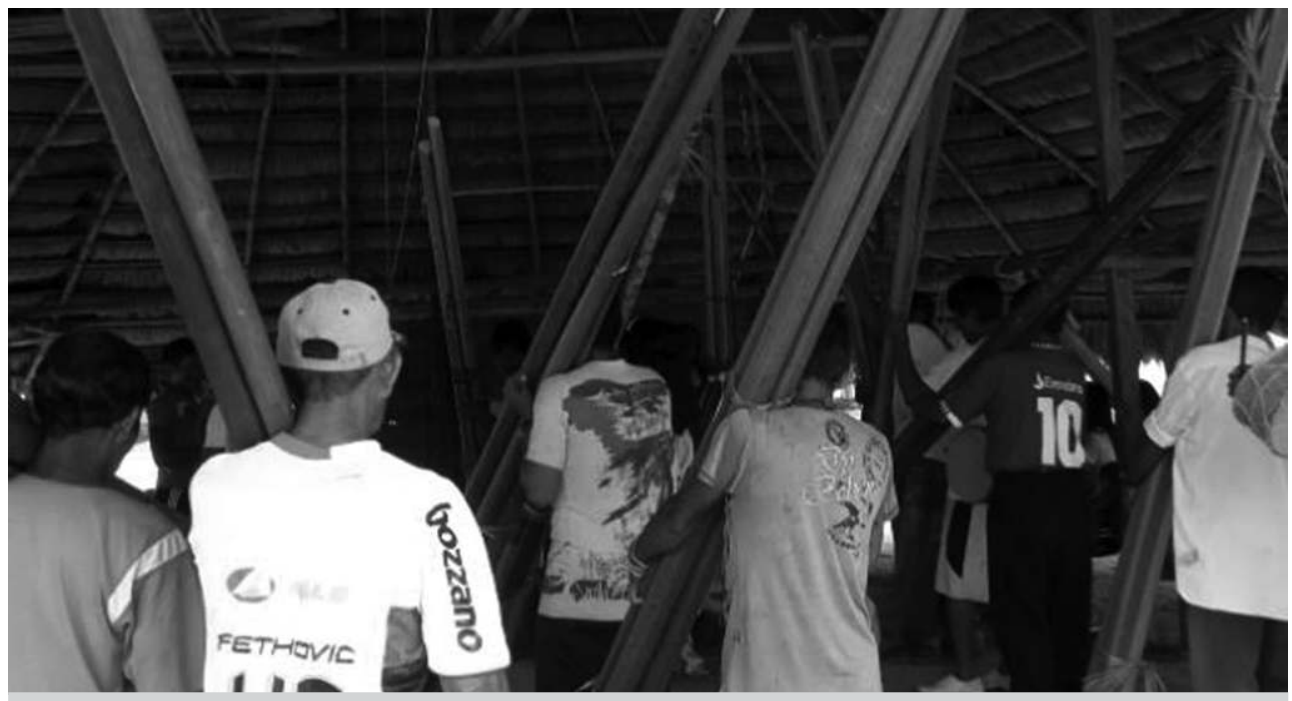

Figura 2 - Talos de buriti trazidos pelos convidados.

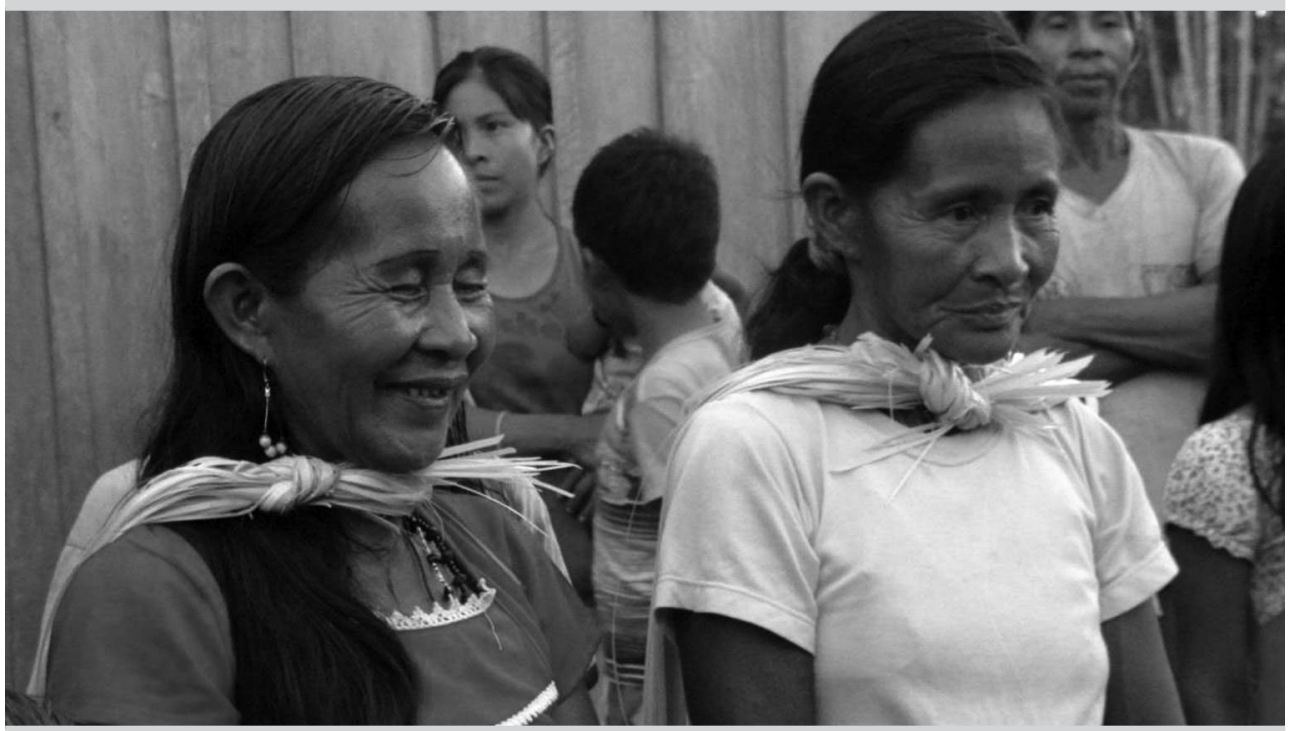

Figura 3 - Mulheres usando adornos de tucum no pescoço.

e anfitriões, e o outro de "plano cosmológico", a troca entre o dono da festa e os mascarados. $^{38}$

38 Tradicionalmente, os ticuna possuem uma grande diversidade de máscaras rituais que se apresentam na Festa da Moça Nova: mawü, õma, to’ü, beru, torama, yewae, taicüré, tchoreruma, yotchiruma, nutchi'i, рорӥ е уигеu são alguns exemplos. Atualmente, as máscaras do macaco caiarara (Cebus albifrons), to'ü, são as mais frequentes nas festas (ver figuras 4 e 5 , abaixo). Para uma apreciação mais extensa sobre as máscaras ticuna, ver Matarezio Filho (2015b, no prelo: 383-398). 
Este tipo de troca que acontece entre a bebida e alguma coisa (carne, por exemplo, para os povos caribe) é bastante recorrente entre os ameríndios. Para os ameríndios, de um modo geral, a carne moqueada cumpre um importante papel como dádiva do grupo que vem para a festa, em troca das bebidas que o grupo anfitrião proverá. De acordo com E. Viveiros de Castro (1986), a oposição complementar entre a carne, trazida pelos convidados, e a bebida, oferecida pelos donos da festa, é difundida por todo o continente. Tal troca conformaria a "armadura simbólica das relações" ou o próprio "arcabouço dos ritos" (Teixeira-Pinto 1997: 350). No caso das trocas rituais arara, povo de língua caribe (Pará, Brasil), Teixeira-Pinto conclui que a "caça é a condição da bebida, como a predação é a da troca” (1997: 365, n. 27).

Em meu livro sobre o ritual de iniciação masculina dos waimiri-atroari, ${ }^{39}$ desenvolvi a hipótese de que este tipo de troca pode ser "mais um 'tema geral caribe', como o sublinhado por Rivière: doadores de cônjuges são superiores aos tomadores, a carne doada pelos convidados é a 'condição real' do ritual arara (Teixeira-Pinto 1997: 383), 'dá-se bebida e faz-se o rito em nome da oferta de carne, jamais o inverso' (Teixeira- Pinto 1997: 365)” (Matarezio Filho 2014 [2010]: 136). Este tipo de troca ritual é bastante comum entre os povos de língua caribe. Para os waimiri-atroari, também não é diferente. Um waimiri-atroari assim relata a importância desta troca: "Nós levamos a carne e o pessoal tem que dar o mingau..." (Vale 2002: 70). Neste caso, existem inclusive evidências linguísticas de que carne e bebida são dons recíprocos por excelência: “... sabemos, por exemplo, que um mesmo verbo é utilizado para designar o ato de colher plantas e o ato de flechar (pykwase), o que estabelece a matéria-prima da carne moqueada e das bebidas como fruto de uma mesma ação, como que dons recíprocos por excelência" (Matarezio Filho 2014 [2010]: 136).

Retomando o exemplo dos índios arara, em seus rituais de Ieipari, os visitantes-mutuns, doadores de carne moqueada, esperam ser "atraídos" pelo canto dos anfitriões-guariba, doadores de bebida fermentada. "A eles é servido o piktu, a bebida fermentada, para que não retornem e comam toda caça moqueada no acampamento, como os porcos do mito" (Teixeira-Pinto 1997: 370-37 1). Ou seja, o oferecimento ritual de bebida na chegada evoca a humanidade dos arara em contraste com a animalidade dos porcos (Matarezio Filho 2014 [2010]: 136-137). Neste sentido, a consequência de não oferecer bebida aos convidados é eles comerem toda a caça, não trazerem ela em troca da bebida. A intensão é que os convidados fiquem, que se tornem parceiros rituais.

39 Povo de língua caribe, localizado cerca de 200 quilômetros ao norte da cidade de Manaus (AM, Brasil), região etnográfica conhecida como guianas. 
"Henley (2001: 198-199) também fala de uma conciliação gradual com os convidados 'invasores' na iniciação masculina dos Panare, povo caribe-guianense. A entrada se dá, resumidamente, da seguinte maneira. Um toque em um chifre de vaca informa os convidados de outro grupo local (panakon), acampados ao lado, que a dança recomeçará. Afirma um panare, com ironia, que os convidados estão realmente zangados, agressivos. Inicia-se uma dança exclusivamente masculina, chamada panakon tchan, literalmente 'os visitantes estão chegando'. O canto evoca o nome de uma mosca atraída pelo cheiro da cerveja. Os visitantes arrombam a entrada da casa ruidosamente, portando galhos e com o rosto pintado de modo bizarro. Fazem uma gritaria e se comportam como se fossem atacar os dançarinos, que continuam cantando como se nada estivesse acontecendo. Tendo falhado em sua intervenção, os panakon deixam a casa. Terminada a dança, os convidados tomam uma bronca. Aos poucos o diálogo se torna mais conciliatório: 'Instead of encouraging them to leave, the hosts are now trying to persuade the panakon to dress the initiands in their new loincloths [...] After an extended show of reluctance, the panakon eventually agree' (idem: 199)" (Matarezio Filho 2014 [2010]: 133).

Com relação à Festa da Moça Nova dos ticuna, podemos interpretar o fato de os mascarados receberem carne moqueada e bebida do mesmo modo que Teixeira-Pinto e Henley interpretam as trocas entre convidados e anfitriões para os arara e panare, respectivamente. Ou seja, o oferecimento de bebida aplaca o investimento violento dos convidados. Contudo, se isso se dá entre os convidados humanos para, por exemplo, os arara, waimiri-atroari e panare apenas para mencionar alguns grupos caribe -, a relação violenta para os ticuna vem da parte de outros seres nocivos do cosmos, personificados nas festas nas figuras dos mascarados. ${ }^{40}$ Estamos aqui no que estou chamando analiticamente de "plano cosmológico". Em se tratando dos mascarados, a intensão é inversa ao que acontece no ritual dos arara, os anfitriões querem que eles vão embora e não causem problemas. Provavelmente, se não recebesse bebida e carne, o mascarado seria bem-sucedido em sua intenção de invadir a reclusão da moça e molestá-la, mas, logo que recebe a carne moqueada e bebe pajauaru, ele vai embora satisfeito. Em outro momento, o dono da festa receberá como "pagamento" o tururi da máscara.

A interpretação de Goulard sobre esta troca com os mascarados vai no mesmo sentido, aplacar o perigo predatório das máscaras:

40 Para outros exemplos de oferecimento de bebida para convidados que chegam como "inimigos" no ritual, ver Matarezio Filho (2014 [2010]: 129-138, especialmente n. 7). Além de mais um exemplo caribe, o dos caribe do Suriname (Roth 1924: 474), apresento dois exemplos tupi, os cinta larga (Dal Poz 1991) e os nhambkwara (Lévi-Strauss 1976 [1949]: 107). 


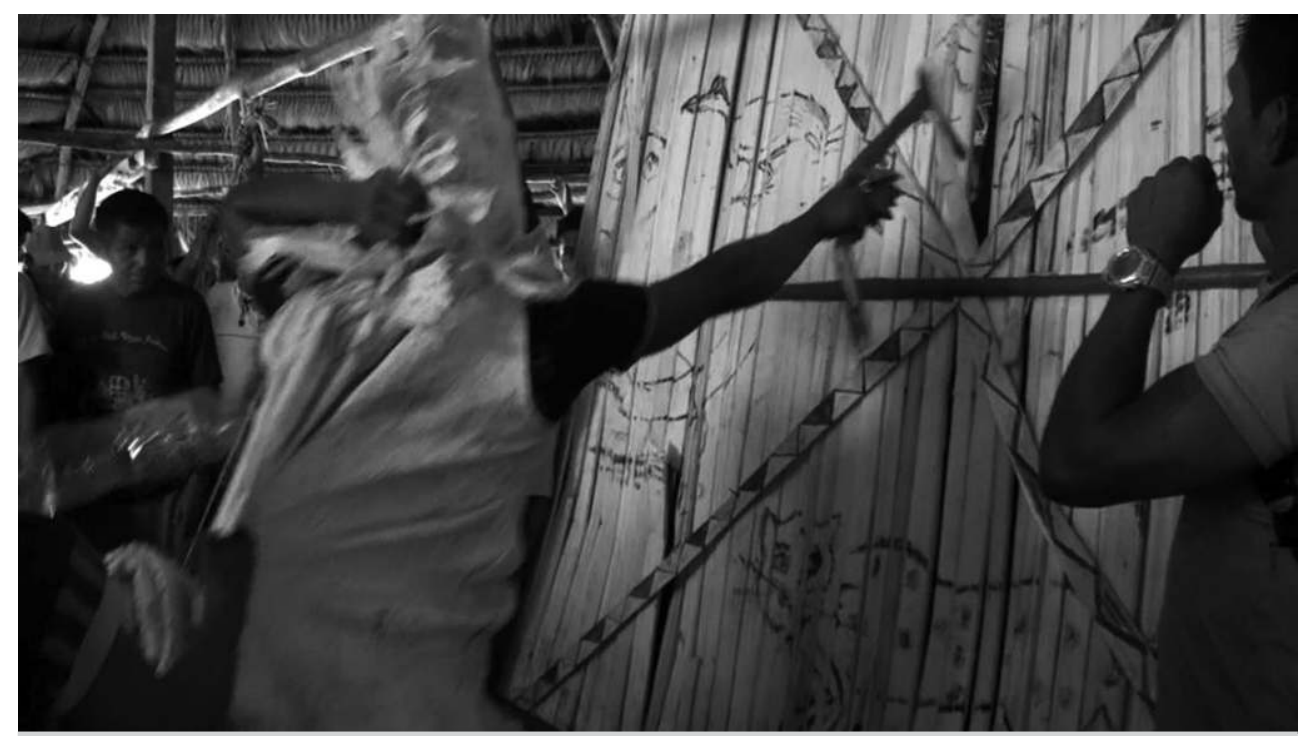

Figura 4 - Mascarado atacando o quarto de reclusão das moças.

"El producto de la caza se inscribe en este intercambio. Se ofrece un trozo de carne ahumada a los que se han presentado con máscaras. Después de un largo ahumado realizado por los hombres, esta carne animal ha sido liberada de su sangre: de roja se ha vuelto negra. Notemos que los animales que la proporcionan a los humanos son representaciones de sus 'padres' que son honrados a través de las máscaras y regados con masato. Entonces, la mediación asegurada por el intercambio de carne ahumada con masato podría ser una respuesta equilibrada para neutralizar una posible devoración, para neutralizar su predación. La carne, puede ser ofrecida ya que las entidades, por intermedio de las máscaras, han tomado suficiente masato; de esta manera son compensados, en vez de la carne humana. La ofrenda regular de esta bebida al mundo 'invisible' se hace explícita en el ritual, como objeto de un intercambio exacerbado para el porvenir de la sociedad" (Goulard 2009: 175).

O trecho acima ainda nos apresenta o importante dado de que algumas máscaras são os "pais" dos animais. Não diria que todas elas: algumas são, como veremos, "pai" do vento (Õma) ou "mãe" da mata (Mawü). Nos rituais que presenciei, o oferecimento de bebida para os "pais" dos animais fica evidente no benzimento dos trompetes de bambu (coîri), em que o "pai" dos queixadas é atraído para beber seu pajauaru na festa.

Apesar de a troca entre convidados e anfitriões ser comum nos rituais ameríndios, há uma diferença fundamental na troca ritual ticuna. Diferentemente dos índios de língua tupi ou caribe, que trocam bebidas por carne, os ticuna 


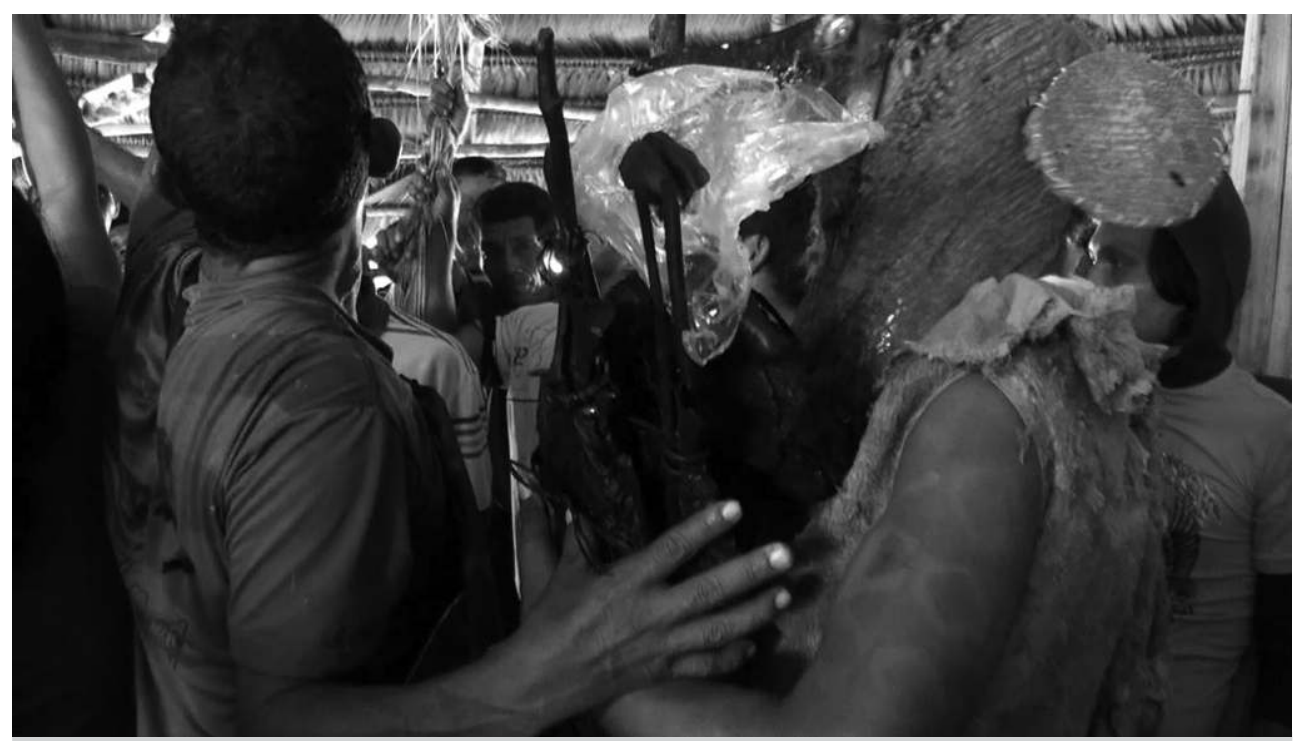

Figura 5 - Entrega de carne moqueada aos mascarados.

trocam bebidas e carne moqueada por máscaras, fibra de tucum e talos de buriti. Ou seja, a oposição encontrada aqui é entre bebida/carne vs. adornos, algo já notado por Lévi-Strauss ao mostrar que os mitos do desaninhador de pássaros, ao passar para a América do Norte, ao invés de narrarem a origem da carne, descrevem a origem dos adornos. Vimos acima alguns dos percursos operados pela mitologia ticuna ao passarmos para os mitos da América do Norte.

Devemos levar em conta, além do fato de Ipi “desaninhar" uma fruta, o fato de esta fruta, apesar de comestível, ser importante na pintura dos corpos. A principal referência ao jenipapo é a informação de que ele é a base de uma tintura para se pintar o corpo de negro, principalmente a "moça nova" em sua festa. Isto é, estamos no plano de algo mais próximo dos adornos do que dos alimentos. A passagem do mito de origem registrado por Goulard (2009: 396) também atesta isso mesmo, ao mostrar os gêmeos depenando águias no ninho e jogando-as para suas irmãs. Isso dá origem aos adornos de penas e se conecta com o tipo de troca que acontece na Festa da Moça Nova, na qual bebidas/ carnes são trocadas por adornos.

Com relação ao "plano sociológico" da troca, Nimuendaju descreve a chegada dos convidados para a festa. Assim como me contou Lorenzo, de Belém do Solimões, de acordo com Nimuendaju, alguns convidados são recebidos no porto com o dono da festa tocando tambor (tutu) e outros parentes percutindo o bastão de ritmo (aru) no chão. "Os convidados vão até a casa, com longas fibras de tucum arrastando para baixo atrás das suas costas" (Nimuendaju 1952: 85). Presenciei este tipo de chegada dos convidados na casa de festas. 
Ao chegarem no ritual, eles recebem imediatamente uma boa porção de bebida e iniciam uma dança com as fibras de tucum que trouxeram. Em seguida, o "copeiro" se encarrega de guardar os presentes. A fibra (nã $\tilde{\imath})$ do tucum (nã ine) é muito útil para tecer a hamaqueira, bolsa (ngeri), braçadeira da "moça nova" (petchina tchacü̈̈), tornozeleira da "moça nova" (pena), pulseira, colar, as cordas do tamborim tutu, etc. Após uma Festa da Moça Nova, é comum ver os donos(as) da festa colocando suas fibras de tucum para secar ao sol.

\section{BIBLIOGRAFIA}

ALMEIDA, Mauro, 2008, “A fórmula canônica do mito”, em Ruben C. de Queiroz e Renarde F. Nobre (orgs.), Lévi-Strauss: Leituras Brasileiras. Belo Horizonte, Editora da Universidade Federal de Minas Gerais, 147-182.

BRETON, André, 2001 [1924], "Manifesto do surrealismo", em A. Breton, Manifestos do Surrealismo. Rio de Janeiro, Nau Editora, trad. Sérgio Pachá, 13-64.

CARVALHO, Fernando Orphão de, 2009, "On the genetic kinship of the languages Yurí and Tikúna”, Revista Brasileira de Linguística Antropológica, l (2): 247-268.

CASTRO, Eduardo Viveiros de, 1986, Araweté: Os Deuses Canibais. Rio de Janeiro, Jorge Zahar Editor/ANPOCS.

CASTRO, Eduardo Viveiros de, 2002, "Perspectivismo e multinaturalismo na América indígena”, em Eduardo Viveiros de Castro, A Inconstância da Alma Selvagem e Outros Ensaios de Antropologia. São Paulo, Cosac Naify, 345-399.

DAL POZ, João, 1991, No País dos Cinta Larga: Uma Etnografia do Ritual. São Paulo, USP, dissertação de mestrado.

DESCOLA, Philippe, e Edson Tosta MATAREZIO FILHO, 2016, "Entre filosofias e etnologias, uma conversa sobre Claude Lévi-Strauss - Entrevista com Philippe Descola”, Cadernos de Campo, 24 (24): 349-367, disponível em < http://www.revistas.usp.br/cadernosdecampo /article/view/97400 > (última consulta em outubro de 2019).

GLENBOSKI, Linda Leigh, 1975, Ethnobotany of the Tukuna Indians, Amazonas, Colombia. s.l., University of Alabama.

GOULARD, Jean-Pierre, 2009, Entre Mortales e Inmortales: El Ser Según los Ticuna de la Amazonía. Lima, CAAAP, CNRS-MAEE-IFEA.

GOULARD, Jean-Pierre, e María Emilia MONTES RODRÍGUEZ, 2013, "Los yurí/juri-tikuna en el complejo socio-lingüístico del Noroeste Amazónico", Liames: Linguas Indígenas Americanas, 13: 7-65.

GREIMAS, A.J., 1973, Semântica Estrutural. São Paulo, Cultrix/Edusp, trad. Haquira Osakabe e Izidoro Blikstein.

GRUBER, Jussara Gomes (org.), 1998, O Livro das Árvores. Benjamin Constant (AM), Organização Geral dos Professores Ticuna Bilingues.

GRUBER, Jussara Gomes, 1999, Instrumentos Musicais Ticunas, apostila manuscrita. 
HENLEY, Paul, 2001, "Inside and out: alterity and the ceremonial construction of the person in the Guianas", em L. Rival e N. Whitehead (orgs.), Beyond the Visible and the Material: The Amerindianization of Society in the Work of Peter Rivière. Oxford, Oxford University Press, 197-220.

LÉVI-STRAUSS, Claude, 1976 [1949], As Estruturas Elementares do Parentesco. Petrópolis, Vozes; São Paulo, EDUSP.

LÉVI-STRAUSS, Claude, 1986, A Oleira Ciumenta. São Paulo, Editora Brasiliense.

LÉVI-STRAUSS, Claude, 1993 [1991], História de Lince. São Paulo, Companhia das Letras.

LÉVI-STRAUSS, Claude, 2004a [1964], O Cru e o Cozido. São Paulo, Cosac Naify.

LÉVI-STRAUSS, Claude, 2004b [1967], Do Mel às Cinzas. São Paulo, Cosac Naify.

LÉvi-STRAUSS, Claude, 2006 [1968], A Origem dos Modos à Mesa. São Paulo, Cosac Naify.

LÉVI-STRAUSS, Claude, 2011 [1971], O Homem Nu. São Paulo, Cosac Naify.

LÉVI-STRAUSS, Claude, e D. ERIBOn, 2005 [1988], De Perto e de Longe. São Paulo, Cosac Naify.

MATAREZIO FILHO, Edson Tosta, 2013, “Trompetes ticuna da Festa da Moça Nova”, em Carlos Sandroni e Alice Lumi Satomi (orgs.), Anais do VI Encontro Nacional da Associação Brasileira de Etnomusicologia, 27-31 maio, 2013, João Pessoa, Paraíba. João Pessoa, UfPB, disponível em < http://www.abet.mus.br/download/AnaisVI_ENABET2013.pdf > (última consulta em outubro de 2019).

MATAREZIO FILHO, Edson Tosta, 2014 [2010], Ritual e Pessoa entre os Waimiri-Atroari. São Paulo, Annablume/FAPESP, prefácio de Márnio Teixeira-Pinto, posfácio de Stephen G. Baines.

MATAREZIO FILHO, Edson Tosta, 2015a, "Trompetas ticuna de la Fiesta de la Moça Nova”, em Bernd Brabec de Mori, Matthias Lewy e Miguel A. García (orgs.), Mundos Audibles de América: Cosmologías y Prácticas Sonoras de los Pueblos Indigenas. Berlim, Iberoamerikanisches Institut/Gebr. Mann Verlag, 121 -135, disponível em < https:/www.iai.spk-ber lin.de/fileadmin/dokumentenbibliothek/Estudios_Indiana/Estudios_Indiana_8_online. pdf $>$ (última consulta em outubro de 2019).

MATAREZIO FILHO, Edson Tosta, 2015b, A Festa da Moça Nova: Ritual de Iniciação Feminina dos Índios Ticuna. São Paulo, USP, tese de doutorado, disponível em < https://goo.gl/zO0 NI8 > (última consulta em outubro de 2019).

MATAREZIO FILHO, Edson Tosta, 2017, "O amadurecimento dos corpos e do cosmos: mito, ritual e pessoa ticuna”, Revista de Antropologia, 60 (1): 193-215, disponível em < https:// goo.gl/LULQ3a > (última consulta em outubro de 2019).

MATAREZIO FILHO, Edson Tosta, 2019, A Festa da Moça Nova: Ritual de Iniciação Feminina dos Índios Ticuna. São Paulo, Humanitas/FAPESP.

MATAREZIO FILHO, Edson Tosta, no prelo, "Perigosos festeiros: as máscaras ticuna 60 anos após Harald Schultz”, em Preservação da Cultura Ameríndia na Coleção Harald Schultz 1942/1965. MAE-USP, Edições Sesc.

MONTES RODRÍGUEZ, María Emilia, 2016, “¿Existen adjetivos en tikuna? (Amazonas colombiano)", Forma y Función, 29 (1): 11-36.

Nimuendaju, Curt, 1952, The Tukuna: American Archeology. Berkeley e Los Angeles, University of California Press.

NIMUENDAJU, Curt, 1982 [1929], “Os índios tukuna”, em Paulo Suess (org.), Textos Indigenistas: Relatórios, Monografias, Cartas. São Paulo, Loyola, introd. Carlos de Araújo Moreira Neto, 192-208. 


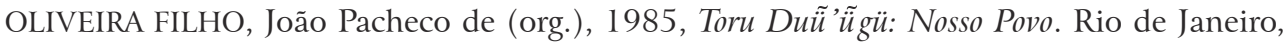
Museu Nacional/UFRJ/SEC/MEC/SEPS/FNDE, Memórias Futuras Edições.

Oliveira filho, João Pacheco de, 1988, “O Nosso Governo”: Os Ticuna e o Regime Tutelar. São Paulo, Marco Zero.

ROTH, Walter Edmund, 1924, "An introductory study of the arts, crafts and the customs of the Guiana Indians", em Thirty-Eighth Annual Report of the Bureau of American Ethnology. Washington, DC, Government Printing Office, 25-720.

SEIFART, Frank, e Juan Alvaro ECHEVERRI, 2014, "Evidence for the identification of Carabayo, the language of an uncontacted people of the Colombian Amazon, as belonging to the Tikuna-Yurí linguistic family", PLoS ONE, 9 (4): e94814.

SOARES, Marília Facó, 2017, "A análise de tempo em Ticuna (Tikuna) revisitada: questões sobre anáfora temporal e sequenciamento temporal", Revista Linguística, 13 (2): 263-285 .

SZTUTMAN, Renato, 2009, “Ética e profética nas Mitológicas de Lévi-Strauss”, Horizontes Antropológicos, 15 (31): 293-319.

TEIXEIRA-PINTO, Márnio, 1997, Iepari: Sacrifício e Vida Social entre os Índios Arara. São Paulo/SP, Eds. Hicitec/ANPOCS, UFPR.

VALE, Maria Carmen Rezende do, 2002, Waimiri-Atroari em Festa é Maryba na Floresta. Manaus, Universidade Federal do Amazonas (UFAM), dissertação de mestrado.

VASQUES, Anita Fermin, 2010, Análise Linguística de um Livro Tikúna, Brasília, Programa de Pós-Graduação em Linguística, Universidade de Brasília, dissertação de mestrado.

Receção da versão original / Original version

Receção da versão revista / Revised version

Aceitação / Accepted
$2017 / 08 / 03$

$2018 / 06 / 06$

$2018 / 11 / 06$ 